Nigerian Journal of Physiological Sciences 22 (1-2): 123-127 CPhysiological Society of Nigeria, 2007

Available online/abstracted at http://www.biolineinternational.org.br/njps; www.ajol.info/journals.njps; www.cas.org

\title{
INCIDENCE OF OCCUPATIONAL STRESS AMONG MEDICAL RADIOGRAPHERS: A POPULATION BASED ZONAL SURVEY.
}

\author{
A. C. UGWU', O. A. EGWU ${ }^{2}$, K. OCHIE ${ }^{3}$, E. O. EWUNONU ${ }^{2}$, K. N. \\ OVUOBA $^{2}$, C. O. NJOKU ${ }^{2}$.
}

${ }^{I}$ Department of Radiology, Federal Medical Center, Abakaliki,

${ }^{2}$ Department of Anatomy, Ebonyi State University, Abakaliki,

${ }^{3}$ Department of Radiography, University of Nigeria, Enugu Campus

E-mal: tonybullng@yahoo.ca

Summary: Biomechanical and Psychosocial stresses are capable of destabilizing any health care professional. The current health sector reform in Nigeria, which lays emphasis on service delivery on a background of very few radiographers, may lead to an increase in stress level. This study investigated the incidence of occupational stress among radiographers in southeastern Nigeria. 50 self-completion questionnaires were delivered to radiographers in the southeastern Nigeria. The questionnaires included questions seeking information on the demographic profile of the radiographer, anatomical regions of biomechanical systems/stress and Visual analogue scale (VAS), which rated job satisfaction and anxiety levels. 32 questionnaires were returned and analyzed statistically. Biomechanical stress was observed in all anatomical regions studied. Job satisfaction rating was $61.3 \%$ and anxiety level was $45.3 \%$. This study has provided a baseline stress level and prevalence among radiographers with which future studies in view of the on going health sector reform in Nigeria could be compared.

Key Words: Biomechanical stress, psychosocial stress, radiographers.

\section{Introduction}

Stress is defined as an interference disturbing individual's well being physically and mentally (Akpa and Afoke, 2005). It is caused by physical and emotional stimuli leading to response by different organs system and the organism as a whole in order to cope with the situation. When it occurs in relation to work, it is called occupational stress, which has 2 divisions; Biomechanical stress and Psychosocial stress.

In southeastern Nigeria where radiographers are very few, there's a tremendous increase in workload, which in theoretical terms predisposes the individual to increased occupational stress and if this is not checked, burnout ensures. Burnout is an individual's reaction to chronic stress (Daughterly, 2002). Compassion fatigue, work environment and job satisfaction have been described as factors that contribute to burnout (Walvwood, 2006). These factors are made more potent by the current health sector reform in Nigeria, which emphasizes service delivery that anchors seriously on patients' satisfaction even though there is no parallel increase in the number of service providers especially among the radiographers.
Numerous authors have described occupational stress in various ways. Tarlo et al (2004) described Dark Room Disease (DRD) as unexplainable multiple symptoms attributed by radiographers to the work environment and stated that it showed significant association with psychosocial stress. Pike et al (1997) and Muir et al (2004) have equally reported the prevalence, nature and cause of musculoskeletal symptoms among medical sonographers.

This study investigated the incidence of occupational stress among radiographers in south-east Nigeria where excess work load persists due to their few number. It is believed that with this study and follow up studies, adequate knowledge of the work limiting factoroccupational tress, will be established in this environment and possible control measures put in place to make the health reforms and the attendant service delivery philosophy in Nigeria an all encompassing effort.

\section{Materials and Method}

Fifty (50) self-completion questionnaires were designed and sent to 50 radiographers in the five (5) South-Eastern States of Nigeria. Questionnaires were used for data collection due to the geographical spread and resources available. 


\section{Questionnaire Design}

The questionnaire was designed to elicit quantitative and qualitative data in order to gather factual and attitudinal information. It contained 29 questions, which were divided into 3 sections. These sections related to:

a) Demographic data - completed by all the respondents

b) Knowledge of occupation stress including its biomechanical (anatomical regions where symptoms are experienced) and psychosocial (job satisfaction and anxiety rating levels) components. Job satisfaction rating and anxiety level were studied using the visual analogue (VAS) of $0 \%$ to $100 \%$.

c) Open ended question on ways to reduce occupational stress among radiographers.

\section{Sampling and Data Collection}

A convenient and purposive sample of radiographers in 10 hospitals across the five States of South-East Nigeria was approached to participate in this study. All the radiographers were registered with the radiographers' registration board of Nigeria (RRBN). Ethical clearance from the Ebonyi State Chapter of Association of Radiographers of Nigeria was obtained. The period of distribution of questionnaire lasted for 3 months and another period of 2 months was allowed before any data analysis took place.

Radiographers who had any form of debilitating illness like diabetes mellitus, arthritis or used walking aids were excluded from this study. A total of 32 questionnaires were returned from the 50 radiogrpahers who were served with questionnaires. The questionnaires were analyzed statistically with SPSS 11.0 software. Descriptive statistical techniques (means and percentages) were used.

\section{Results}

A total of 32 questionnaires were returned within 2 months. They were completed by twenty-eight males (28) and four (4) females. Responses were received from all the SouthEastern hospitals used in this cohort study. Sixteen (16) more questionnaires were received after 3 months but were not included in the data analysis for this paper.

Table 1: Prevalence of Symptoms Experienced by Radiographers

\begin{tabular}{|c|c|c|}
\hline $\begin{array}{c}\text { Anatomical } \\
\text { Region }\end{array}$ & $\begin{array}{c}\text { Symptoms } \\
\text { Experienced }\end{array}$ & $\%$ Prevalence \\
\hline \multirow[t]{3}{*}{ Neck } & Pain & $18.8 \%(n=6)$ \\
\hline & Ache & $6.3 \%(n=2)$ \\
\hline & & $18.8 \%(n=6)$ \\
\hline Shoulder & Pain & $12.5 \%(n=4)$ \\
\hline Elbow & Pain & $18.8 \%(n=6)$ \\
\hline Wrist & Pain & $6.3 \%(n=2)$ \\
\hline \multirow[t]{3}{*}{ Finger/hand } & Pain & $6.3 \%(n=2)$ \\
\hline & Ache & $12.5 \%(n=4)$ \\
\hline & Numbness & $6.3 \%(n=2)$ \\
\hline $\begin{array}{l}\text { Dorsum of } \\
\text { hand }\end{array}$ & Numbness & $6.3 \%(\mathrm{n}=2)$ \\
\hline \multirow[t]{3}{*}{ Eyes } & Pain & $6.3 \%(n=2)$ \\
\hline & Ache & $6.3 \%(\mathrm{n}=2)$ \\
\hline & Itching & $6.3 \%(n=2)$ \\
\hline \multirow[t]{2}{*}{ Upper-back } & Pain & $37.5 \%(n=12)$ \\
\hline & Ache & $6.3 \%(n=2)$ \\
\hline Middle-Back & Pain & $25.0 \%(n=8)$ \\
\hline Middle-Back & Ache & $12.5 \%(n=4)$ \\
\hline \multirow[t]{2}{*}{ Hip } & Pain & $25.5 \%(n=8)$ \\
\hline & Ache & $6.3 \%(n=2)$ \\
\hline \multirow[t]{2}{*}{ Lower-Back } & Pain & $31.3 \%(n=10)$ \\
\hline & Ache & $6.3 \%(n=2)$ \\
\hline
\end{tabular}


Table 2: Descriptive Statistics for Job satisfaction Rating and Anxiety Level

\begin{tabular}{|c|c|c|c|}
\hline & $\begin{array}{l}\text { Number (N) of } \\
\text { Radiographer }\end{array}$ & $\begin{array}{l}\text { Mean } \\
\text { Score }\end{array}$ & $\begin{array}{l}\text { Standard } \\
\text { Deviation (SD) }\end{array}$ \\
\hline $\begin{array}{l}\text { Job } \\
\text { satisfaction }\end{array}$ & 30 & $61.3 \%$ & 11.9 \\
\hline Anxiety level & 30 & 45.75 & 18.8 \\
\hline
\end{tabular}

Table 1shows the percentage prevalence of symptoms in the anatomical regions studied. Upper back pain was the most prevalent (37.5\%). This was followed by lower back pain $(31.3 \%)$, Hip pain and midback pain $(25.0 \%)$, and shoulder, Neck and wrist pains $918.8 \%$ ).

Table 2 shows descriptive data for job satisfaction and anxiety level. With job satisfaction rating being $61.3 \pm 11.9 \%$ and anxiety level being $45.7 \pm 18.8 \%$.
Table 3 shows number of working days in a week and that $60.0 \%$ (18) respondents work for 5 days in a week. Table 4 shows descriptive data on the kind of chair used with most of the respondents $(60 \%)$ using stationary and soft seats. $50 \%$ of the respondents observe break period at most once a day while $50 \%$ do not have time for breaks.

Table 3: Working Days in a week

\begin{tabular}{lccccc}
\hline No of days & 1 & 2 & 3 & 4 & 5 \\
\hline $\begin{array}{l}\text { No of } \\
\text { Radiographer } \\
\% \text { No of }\end{array}$ & 2 & 2 & 2 & 18 & 6 \\
\begin{tabular}{l} 
Radiographer \\
\hline
\end{tabular} & $6.7 \%$ & $67 \%$ & $6.7 \%$ & $60.0 \%$ & $20.0 \%$ \\
\hline
\end{tabular}

Table 4: Kinds of Chair used in the Resting Room/receptor

\begin{tabular}{ccccccc}
\hline & $\begin{array}{c}\text { Rotating } \\
\text { and soft }\end{array}$ & $\begin{array}{c}\text { Rotating } \\
\text { and hard }\end{array}$ & $\begin{array}{c}\text { Stationary } \\
\text { and hard }\end{array}$ & $\begin{array}{c}\text { Stationary } \\
\text { and soft }\end{array}$ & $\begin{array}{c}\text { No } \\
\text { chair }\end{array}$ & Total \\
\hline $\begin{array}{c}\text { No of } \\
\text { Radiographer } \\
\% \text { No of }\end{array}$ & $(2)$ & $(2)$ & $(2)$ & $(12)$ & $(2)$ & 20 \\
$\begin{array}{c}\text { Radiographer } \\
\text { Ragran }\end{array}$ & $10.0 \%$ & $10.0 \%$ & $10.0 \%$ & $10.0 \%$ & $10.0 \%$ & $10.0 \%$ \\
\hline
\end{tabular}

\section{Discussion}

Result from this study have shown that radiographers in South-East Nigeria experience work-related biomechanical stress symptoms in almost all anatomical regions examined. Upper back musculoskeletal symptoms of pain were the most prevalent $(37.5 \%)$. This could be traced to the constant stress and strain of muscles of the upper back, like the trapezius, Rhomboids major and minor, levator scapula and some scalenei muscles in the course of moving static and possibly old x-ray units. These muscles especially the trapezius are usually affected by excess hand activities (Roman Lui et al 2001), which occurs during manipulation of imaging equipment like X-ray machines. The accompanying prevalence of lower back, middle back, neck and even eyes could be attributed to the indirect concerted effort by the musculoskeletal components of the back and neck to keep the head steady, permitting vertical and horizontal scanning adopted for eye head co-ordination
(Rabischong, 1992) and mental attentiveness. This is done during the assessment and passing of radiographs prior to reporting. The occurrence of upper extremity biomechanical symptoms could be explained from the fact that the extremity is used to control movement of tube head and operation of other radiographic equipment.

In a similar study involving medical students, $83.4 \%$ of the students experienced musculoskeletal symptoms, which were attributed to stress related work overload (Egwu et al, 2006). Thus, biomechanical and psychosocial components of occupational stress are strongly interwoven. Stress experienced in the practice of radiography has the potentials to deter not only students from continuing with the training but also could cause brain drain. Psychosocial stress among radiographers was assessed using job satisfaction rating and anxiety induced by workload. Job satisfaction ratings by respondents were less than $70 \%$. It is known that psychological conflicts and the 
individuals inability to adapt to work are capable of generating negative moods, emotional upsets and other maladies that affect not only mental health but also the neurovegetative functioning of the mental but also the neurovegetative functioning of the organism (Casanova-sotolongo et al, 2003). Among Sonographers, three major stressors have been reported: clinical correlation ambiguity, demanding work schedule and taking call (Penny, 2005). Clinical correlation ambiguity may occur when a radiographer lacks enough clinical knowledge of his imaging findings that will give a good base for judgement. This was not reported by any radiographer in this study and could probably be caused by the fact that radiographers are not always involved in film interpretation unlike their counterparts in the U.K. and other developed countries.

Anxiety level of respondents (45.7\%) relates mainly to psychosocial stress. With its persistence, there could be a gradual build up of stress on the individual leading to palpitation, dilation of pupil, increased velocity of blood flow and increased muscle activation.

\section{Limitations of the Study}

Although this study yielded some very useful information, it does have limitations that should be addressed in future studies. The sample population consisted of radiographers in southeastern Nigeria who were registered with radiographers' registration board of Nigeria (RRBN), which does not represent the whole southern Nigeria that habours the greatest percentage of radiographers in Nigeria.

\section{Future Research}

A number of questions can emerge from this study, which could be addressed, in future research in a larger sample population from the southern Nigeria. In this study, anxiety and job satisfaction as sources of psychosocial stress were studies. A logical question to investigate are the extent to which workload, poor remuneration. Government's disinterest in staff welfare, family influence, fear and avoidance, illness behaviours and other psychosocial variables affect anxiety and job satisfaction in radiography practice. The research could focus on trying to determine whether radiographers are developing apathetic attitude to deal with chronic stressors on work place environment. Research control groups of radiographers with specific stress management situations could possibly help determine how best to evaluate solutions to the ramifications of the problems of stress within the radiography profession in Nigeria.
Further research could include more variables, such as coping, adaptation techniques, intervention, support group, social environment, and quality-of-life programs. Another research project could include identifying if the curriculum in radiography education in Nigeria attempts in any way to prepare students for realistic clinical environments. It should further investigate if these graduates have different coping and managing skills for stress than the graduates from programmes without this preparation. A research study comparing how levels of stress for radiographers compare to other health professions could be performed in a larger sample population.

\section{Conclusion}

Finally, medical examination of radiographers should be encouraged from time to time to avert the setting in of degenerating psychosocial and musculoskeletal stress conditions. Such studies, as this, should be carried out frequently and used as particular detectors of occupational stress in the study serves as a baseline.

\section{References}

Akpa, A. O. C. and Afoke, A. O. (2005). Stress: Causes, effects and human survival strategies. J. Biomed. Africa. 3: (2): 3-5).

Casanova-sotolongo, P., Lima-Mompo, g., Aldana-Vilas, L., Cassanovacarrillo, P., Casanova-Carrilo, C. (2003). Occupational Stress as one of the concerns of present day public health services. Rev. Neurol. 36 (6): 565-567.

Daughterly, J. M. (2002). Burnout: How Sonographers and vascular technologists react to chronic stress. J. Diag. Med. Sonography. 18 (5): 305-312.

Egwu, O. A., Ewunonu, E. O., Eteudo, A. N., Ovuoba, K. N., Ugwu, A. C., Akpa, A. O. C., Okechi, O. O. (2006). Prevalence of Neck, Upper back and chest musculoskeletal symptoms among, medical students. J. Expt. \& Clin. Anat. 5(1).

Miur, M., Hrynkow, P., Chase, R., Boyce, D., Mdean, O. (2004). The Nature case and extent of occupational musculoskeletal injuries among sonographers. J. Diag. Med. Sinography. 20(5): 317-325.

Penny, S. M. (2005). Stressors and employee retention in diagnostic medical sonography department. J. Diag. Med. Sonography. 21:152-155.

Pike, I. Russo, A., Baker, J. P., Lessoway, V. A. (1997). The prevalence of Musculoskeletal disorders among diagnostic medical 
sonographers. J. Diag. Med. Sonography. 13(5): 219-227.

Rabischong, P. (1992). Functional Anatomy of the Spine and spinal cord in manelf. C (ed) Imaging of the spine and spinal cord. Raven Press New York.

Roman Liu, D., Tokarski, T. Kaminska, J. (2001). Assessment of the musculoskeletal load of trapezius and deltoid muscle during hand activity. Int. J. Occup. Saf. Ergon. 7 (2):179-193.

Tarlo, S. M., Liss, G. M., Greene, J. M., Purdham, J. Maccaskell, L. N., Kippen, H.
Kerr, M. (2004). Work attributed symptom clusters (darkroom disease) among radiographers versus physiotherapists: associations between self reported exposures and psychosocial stressors. Am. J. Ind. Med. 45(6): 513-521.

Walvwood, H. (2006). Understanding sonographers burnout. J. Diag. Med. Sonography. 22 (3): 200-205.

Received: $24 / 7 / 2007$

Accepted: 15/11/2007 